Received September 25, 2018

Revised November 27, 2018

Accepted December 10, 2018

\title{
China's Belt and Road Initiative in Central and Eastern Europe
}

\author{
EMILIAN KAVALSKI*
}

\begin{abstract}
The Central and East European (CEE) part of the Eurasian landmass is often overlooked in the conversations on contemporary geopolitics. Yet, owing to China's investment in the CEE countries, the region has been subject to growing strategic attention. This article offers a brief overview of the history of this relationship by focusing on the " $16+1$ " mechanism. Nestled within the broader Belt and Road Initiative, the " $16+1$ " has provided a unique regional arrangement for extending Chinese influence in the sixteen CEE countries. The article inquires whether there is something else than the instrumental economic reasoning for the willingness of CEE countries to partner with China. The analysis detects four distinct (and mutually exclusive) strategic narratives motivating the participation of CEE states in the " $16+1$ " mechanism. The study concludes with an enquiry on China's preparedness to respond to such identity geopolitics not only in the CEE region, but throughout the vast expanse covered by the BRI initiative.
\end{abstract}

Keywords: Belt and Road Initiative, China-EU relations, China-CEE cooperation, " $16+1$ " mechanism, strategic narratives

* Li Dak Sum Chair Professor of China-Eurasia Relations and International Studies, University of Nottingham Ningbo China; E-mail: emilian.kavalski@notthingham.edu.cn DOI: 10.16934 isr.19.2.201812.13 


\section{INTRODUCTION}

Geopolitics is a complex and capricious game. Actions aimed to secure the long-term interests of states oftentimes backfire and have the opposite or completely unexpected, yet equally unintended effect. With its new-found appetite for global engagement, China is beginning to be confronted with the unpredictability of global life. In July 2018, many were puzzled when Johannes Hahn, the European Commissioner for the European Neighbourhood Policy and Enlargement Negotiations, singled China for his denunciation of external meddling in European international interactions. In a time when tensions with Putin's Russia seemed only to be escalating, Hahn's criticism of Beijing appeared unexpected. In particular, by focusing on China's relations with Central and East European (CEE) countries, Hahn insinuated that Beijing is populating the region with "Trojan horses" - that is, countries with split loyalties and prone to undermining the European integration process. As he put it: "I think we should be aware about the strategic concept of China and react in an appropriate manner. I think that this would be one of the greatest challenges for Europe" (quoted in Heath and Gray 2018). This was far from an isolated diatribe. Earlier in the year, the French President Emmanuel Macron warned that some European countries and it was quite clear that he had the CEE states in mind - seem to prioritise the Chinese interests, "sometimes even at the expense of European interests". In this respect, the German Foreign Minister Sigmar Gabriel indicated in February 2018 that unless the EU "develops a [common] strategy regarding China then China will succeed in dividing Europe" (South China Morning Post 2018). He had earlier irked Beijing by demanding that it observes a "One Europe" policy just as Brussels complies with the "One China" policy (Poggetti 2017).

The context for this criticism is China's growing involvement in the CEE countries. The allegation is that such engagement provides China not only with access to European markets, but also buys political influence in the region. As evidence of such nefarious plans, critics of China's policy in the region point to Greece's veto of the EU's condemnation of China's human rights record at the UN in June 2017 (The Guardian 2017), or East European support for Beijing's stance on the South China Sea (Emmott 2016). Yet, the proposition here is that Brussels is neither particularly distressed by the actual amount of Chinese investments, nor by the growing number of meetings between Chinese policy-makers and executives and their CEE counteracts. After all, the $€ 15$ billion of Chinese investments in the CEE region, are a mere fraction of the $€ 164$ billion that Beijing has poured in the Western part of the continent (Pepe 2017, 5), and West European leaders have far more privileged bilateral relations with China than their CEE counterparts (Van Oudenaren 2018). Instead, what the EU finds concerning is China's staying power implicit in the creative institutional 
architecture that it is introducing in the continent. In this respect, China both participates in the existing framework of European international relations and, through OBOR, it engages in constituting "a qualitatively different regional relationality" (Fierke and Antonio-Alfonso 2018, 202 Kavalski 2006b). The so-called " $16+1$ " mechanism for cooperation between China and the CEE states offers one of the clearest indications of China's strategy of "reinterpreting (parts of) the international order by integrating it" (Benabdallah 2019, 2).

Under the auspices of the " $16+1$ " mechanism, China has been developing relations with sixteen CEE states: Albania, Bosnia and Herzegovina, Bulgaria, Croatia, the Czech Republic, Estonia, Hungary, Latvia, Lithuania, Macedonia, Montenegro, Poland, Romania, Serbia, Slovakia, and Slovenia. Part of the large-scale Belt and Road Initiative (BRI), the "16+1" is tasked with facilitating the projection of the BRI to the CEE region. To varying degrees, all CEE countries participating in the " $16+1$ " mechanism have shown that apart from the "hardware" of investment opportunities provided by the BRI, their engagement with Beijing is also driven by the "software" of ideas and values that backstops China's connectivity projects (Kavalski 2006c Ling 2018; Ling and Perrigoue 2018). For instance, the Hungarian PM Viktor Orbán was speaking for many of his counterparts when at the closing of the 2016 " $16+1$ " summit in Riga he declared that while the EU "is struggling with the problem of economic stagnation, isolating ourselves from the world would be the worst response. We believe that we must open up and clearly it is beneficial for us to open up to China" (Cudworth et al. 2018; Kavalski 2003a; Pavlićević and Kratz 2018). The implication is that China is gradually starting to be perceived - at least by some in the CEE region - as offering a viable alternative to the EU project. This context provides a unique opportunity to explore the motivations driving various countries to partner with China.

Paradoxically, this still is an overlooked issue in the current debates on the BRI. In other words, while the value of the BRI for China is always already assumed, what is the value of the BRI for China's counterparts? To the extent that this question is ever considered, its responses rarely go beyond the economic incentive for China's BRI partners. Yet, is participation in the BRI always and only purely economic or does it reflect some other motivations as well? If, indeed, (some) countries participate in the BRI for reasons other than economic benefits, is China aware of these dynamics and how does it respond to such idiosyncratic motivations? In responding to these queries, this analysis looks at the experience of the CEE countries. The spotlight of the BRI is usually on the Asian (be they Central Asian, South Asian, or Southeast Asian) or African participants. Yet, Europe - especially, the post-communist region - forms an important part of the BRI. In fact, CEE was among the best represented regions at the 2017 Belt and Road Forum launching the initiative: of the 28 heads of state or 
government 4 were from the region (the Czech Republic, Poland, Hungary, and Serbia), while Romania sent a delegation led by the country's deputy prime minister.

Such list lends itself easily to a geopolitical reading of the relationship: the five countries represent the five largest territorial CEE states located at crucial economic and infrastructure junctures in Europe. Yet, such explanation says more about China's reasoning for involving these countries in the BRI than that of the CEE countries themselves. As it would be explained, while economic factors are not insignificant, for most CEE countries the BRI also offers novel platform for the (re)articulation of domestic identity politics. Majority of these identity games relate to distinct politicizations of the international identities of CEE states (Katrandzhiev 2018; Zolkos and Kavalski 2016). This analytical framework of this study benefits from an extensive review of the relevant scholarly and policy literatures, punditry and media accounts, as well as official documents, declarations, and statements. The investigation also profits from extensive first-hand participatory observation of international high-level meetings and events elated with the "16+1" mechanism (Pavlićević 2018)

The study detects four distinct identity narratives that can be inferred from the official statements of the governments of CEE states: (i) we are European some CEE countries use the BRI to (re)assert their European identity; the point here is to confirm the commitment of those countries to EU membership and the principles of liberal democracy, and to counter the advances of Russia; (ii) we are independent Europeans - some CEE countries use the BRI to emphasize their foreign policy independence from the EU, articulate a pro-Russian stance, and indicate their suspicion of liberal democratic principles; (iii) we are distinct East Europeans - some CEE countries use the BRI as a tool of intra-CEE differentiation; the point here is that some CEE countries are more worthy of Chinese investment than others; (iv) we are who we say we are - some CEE countries use the BRI to affirm their own self-identity vis-à-vis contestation from the international community. The concluding section brings together these strategic narratives and assesses briefly the opportunities and challenges that China is likely to face in the implementation of the BRI project in the CEE region.

\section{WHAT IS THE “16+1”?}

China's growing involvement in the countries of Central and East Europe (CEE) offers a qualitatively new context for Sino-EU relations. Whilst such policy diversification has become commonplace across much of the so-called developing world, its emergence in the CEE region seems to challenge the very identity of the EU (Cho and Kavalski 2018b; Vangeli 2018). It was the very 
willingness of the post-communist countries to internalize the "European model" that has convinced the EU of its ability to set the domain and range of legitimate international behaviour. In this way, the CEE states provided the enabling environment for the international outreach of the EU. As many have stated, the EU's influence has always been subject to contestation beyond the realm of its accession programs, however its appeal - both material and normative - has never appeared in doubt within the domain circumscribed by EU-membership and prospect of membership. It is for this very reason that many commentators have long been insisting that the EU is a continental rather than a global international actor (Kavalski 2004). Yet, in the wake of the Eurozone debt crisis and the Brexit referendum in the UK, there seems to be a reversal in roles - not only is the EU no longer the dominant partner in the Sino-European relationship; the coherence of the international identity of the EU appears to be challenged by the growing dependence of both the EU member states and EU candidate countries on Chinese trade.

In this setting, many have started to interpret the gargantuan investments, trade opportunities, and cooperation initiatives of the BRI as a new mode of globalization (if not global governance) pivoted on China. Especially, in the context of an apparent US withdrawal from multilateralism and various international commitments, the conversation seemingly naturally has focuses on China. For instance, while in the immediate post-Cold War period China appeared to be a reactive adopter of international norms, Beijing has been quite willing to adopt activist stance since the appointment of Xi Jinping to the presidency (Cho and Kavalski 2018a; Pempel 2005). In this respect, the BRI has become probably the most conspicuous vehicle of China's international influence - namely, such expansive global connectivity projects legitimize the emergence of alternative conceptualizations of political goods in global life and the appropriate way(s) for their attainment. In particular, Beijing seems keen to secure support for its global vision of a pluralist global order in which all countries will be able to exercise their right to pursue their own path of development. As such, many commentators claim that the BRI demonstrates China's transformation from a good and responsible global "game player" to a global "game maker". In this respect, the " $16+1$ " mechanism has increasingly started to be seen as an indication of China's capacity to use its economic prowess to contest dominant norms, rules, and arrangements (Kavalski 2013a; Pavlićević and Kratz 2018). It would therefore be worthwhile to outline the make-up and brief history of the " $16+1$ ".

The "16+1" represents quite a heterogeneous group. Of the sixteen participating CEE states, eleven are EU member states (five of which are also members of the single currency Euro-zone), four are EU candidate countries, and one is a potential candidate state. The origins of the " $16+1$ " mechanism predates 
the BRI itself. The formation of a dedicated platform for China-CEE relations was suggested already in 2011 by Wen Jiabao, the then Chinese Premier, at a meeting in Budapest (Hungary) of the China and Central and Eastern European Countries Economic and Trade Forum (Xinhua 2011). The following year, the Initiative for Cooperation between China and Central and East Europe was launched by Wen Jiabao on April 2012 in Warsaw (Poland). Subsequently, this has been lauded as the inaugural summit of the " $16+1$ ". The " $16+1$ " mechanism provides a unique framework for the formalization of China's post-Cold War interests and relations with the CEE region. A dedicated Secretariat for Cooperation between China and CEE countries was established within the Chinese Ministry of Foreign Affairs. Beijing also set up a special credit facility providing CEE countries with preferential loans for joint infrastructure projects. All these are part of a "Twelve Measures Program" outlined by Wen Jiabao at the Warsaw Summit. The " $16+1$ " is often treated as a carbon copy of either the Forum on China-Africa Cooperation (FOCAC), or the Shanghai Cooperation Organization (SCO). It is easy to find evidence for such assertions. For instance, at the 2012 Warsaw Summit, China proclaimed that all the CEE countries are part and parcel of the developing world. Such positioning has then allowed Beijing to treat the " $16+1$ " mechanism as an integral part of China's growing paraphernalia of initiatives for South-South cooperation (Kavalski 203b; Pavlićević and Kratz 2018; Vangeli 2017).

At the 2013 Summit of the "16+1" in Bucharest (Romania), the participants agreed on specific Guidelines for Cooperation between China and Central and East European Countries. These were very much updates on the "Twelve Measures" proclaimed the previous year at Warsaw. It has since become a standard. Guidelines are being updated at every subsequent summit of the "16+1". At the same time, the Bucharest Guidelines sought to align the " $16+1$ " with the broader objectives of the BRI (McCullock and Kavalski 2005). The 2014 Summit in Belgrade (Serbia) reinforced the centrality of the initiative to the BRI and reiterated Beijing's interests in closer cooperation with the CEE region. To that effect, the Belgrade Summit established a China-CEE Investment Cooperation Fund in order to strengthen the trade links and economic partnership between Chinese and Central and East European enterprises. It is this setting that large scale connectivity projects - such as the BRI - presage an understanding of international action and agency - both cognitively and affectively - as simultaneously shaped and mediated by ethical obligations and commitments to others (the structure and content of which is acquired through the very relationships by which ethical obligations and commitments to others are disclosed) (Kavalski 2010b; Ling 2019). This experience reframes geopolitics into a relational practice simultaneously attuned and open to the contradictions, challenges, and opportunities of a dynamic and unpredictable global life. In other 
words, the geopolitics of China's global outreach reveals an entanglement in the very practices through which ideas of sociality are shared (Katzenstein 2005; Kavalski 2019).

Yet, to all intents and purposes, it was the 2015 Summit in Suzhou (China) that seemed to draw international attention to the "16+1" mechanism. The Suzhou Summit was the first meeting attended by all the heads of state and/or government of CEE countries. Hosted by the Chinese Premier Li Keqiang, the Suzhou Summit seemed to presage a qualitative geopolitical shift in European affairs. In fact, some commentators started talking of the re-emergence of a new "Eastern Bloc" reminiscent of the Cold War division of the continent. However, rather than a Soviet "Iron Curtain", this time - and perhaps paradoxically - it was a Chinese connectivity project that is alleged to be driving a wedge in the continent. In addition to an annual update of the guidelines for cooperation, the 2015 Suzhou Summit outlined a "Medium Term Agenda for Cooperation between China and Central and East European Countries". The aim of the Agenda is to strengthen the cooperation between China and CEE countries by further institutionalizing and formalizing the " $16+1$ " arrangement. It specifies the appointment of a Special Representative for Cooperation between China and Central and Eastern European Countries at the Chinese Ministry of Foreign Affairs; the establishment of bi-annual meetings of the Secretariat of the National Coordinators of the " $16+1$ " - one in China and one in one of the CEE countries; and the convening of quarterly meetings between the Secretariat and the embassies of the CEE countries. At the same time, the Agenda outlines the establishment of annual benchmarks and deliverables to trace the impact of the " $16+1$ " arrangement across the various sectors in which China and CEE countries cooperate (Kavalski 2018b).

Since Suzhou, the "16+1" has held annual summits attended by the Chinese Premier and the heads of state and/or government of the CEE countries. The latest one ${ }^{-}$and the eight for the initiative - took place in July 2018 in Sofia (Bulgaria). While, in many ways, it continued the tradition established at the 2015 Suzhou Summit, it also marked a significant change. To begin with, as the vagaries of circumstance would have it, the host country - Bulgaria - held the rotating presidency of the Council of the EU. This was a first for the " $16+1$ ". In this respect, Sofia found itself at the crossroads of two competing connectivity projects spanning the Eurasian landmass: on the one hand, the EU's continental integration program pivoted on Brussels and, on the other hand, the transcontinental Silk Roads initiative promoted by Beijing. The EU put immense pressure on Bulgaria - both informally, behind closed doors, and through official channels - to cancel the "16+1" summit. In fact, the criticism of China by various European politicians quoted in the introductory section of this study, were part of the EU campaign both to compel Bulgaria to cancel the summit and to 
remind the other CEE countries that their strategic interests and allies are in Europe. However, the " $16+1$ " is more than an annual summit (Pavlićević and Kratz 2018).

Since the launch of the 2015 Suzhou Agenda, the "16+1" has morphed into a fully-fledged regional organization for CEE. This pattern proffers a relational regional architecture attuned to the transient constellations of factors and actors that impact on the content, trajectories, and possible transformations in any social relationship. The underlying aim is to aid the ability to engage an ever-changing world. Regionalization - especially, the practice of initiating regional forums in various global locales (such as the SCO and FOCAC) appears to have furnished China with a convincing platform for allaying the fears of other actors about its proactive international behavior (Fierke and Antonio-Alfonso 2018; Kavalski 2010a). Consequently, the proposition of a community-building dimension of Chinese foreign policy should not be surprising. As a foreign policy approach, it emerges out of idiosyncratic push-and-pull factors that shape Beijing's attempt to position itself as a responsible and reliable international actor. Regionalization has, thereby, been interpreted as a strategy for acquiring "the power to avoid conflict" (Kavalski 2007b, 30; Pavlićević and Kratz 2018). Yet, as demonstrated in Table 1, the " $16+1$ " mechanism has permeated diverse sectors of the economic, social, and political life of CEE countries (Kavalski 2017a).

\section{TABLE 1: INSTITUTIONS WITHIN THE "16+1" MECHANISM}

\begin{tabular}{ll}
\hline \multicolumn{1}{c}{ Institution } & Headquarters \\
\hline Union of Colleges and Universities & Joint management \\
\hline Agency for Tourism Promotions & Hungary \\
\hline Contact Mechanism for Investment Promotion & Poland \\
\hline Commercial Union & Poland and China \\
\hline Mayors Association & Czech Republic \\
\hline Association for the Promotion of Agriculture & Bulgaria \\
\hline Technology Transfer Center & Slovakia \\
\hline Think Tanks Network & Chinese Academy of Social Sciences \\
\hline Logistics Cooperation Union & Latvia \\
\hline Transportation Infrastructure Cooperation Union & Serbia \\
\hline Forestry Cooperation Union & Slovenia \\
\hline Energy Cooperation Union & Romania \\
\hline Association for Maritime Cooperation & Poland \\
\hline Center for Cultural Cooperation & Macedonia \\
\hline Health Cooperation Union & To be agreed \\
\hline Art Cooperation Union & To be agreed \\
\hline Customs Cooperation Union & To be agreed \\
\hline Source Liu (2017); Vang
\end{tabular}

Source: Liu (2017); Vangeli (2017) 
Such dense institutionalization of the " $16+1$ " is quite peculiar both for China and for the BRI initiative. While the BRI uses regional appellations for the operationalization of its outreach, in practice, the BRI works through - and China, in general, has expressed preference for - contractual bilateral relations (Heath and Gray 2018; Kavalski 2009). Yet, in the case of the CEE, the regional template did not exist prior to the establishment of the "16+1" in 2012 (which was not the case for either Southeast Asia, Central Asia, the Middle East or any of the other regions to which the BRI is being extended). It is true that the majority of the sixteen CEE countries have had some shared Cold War experience, yet their experience of both communism and Soviet control were not uniform. After the fall of the Berlin Wall each of them has adopted its own path of post-communist development, which has led the sixteen CEE countries to diverge even further from one another. Even in the context of the EU and NATO enlargement, the sixteen were never grouped together and were both perceived and treated differently (Fierke and Antonio-Alfonso 2018; Smith and Kavalski 2010). In this respect, neither during the Cold War, nor in its wake have these countries participated in shared regional projects. In this respect, the CEE of the " $16+1$ " is a completely Chinese invention, which seems to ignore prior and persisting differentiation among the CEE estates. At the same time, it is curious to know, how China decided who is going to be in and who is going to be left out of the " $16+1$ " mechanism. For instance, neither Kosovo, nor Ukraine or Moldova have been invited to participate in this arrangement (Kavalski 2011; Neumann 1999).

The driving force underpinning the " $16+1$ " appears to be the practice of doing things together which affords ongoing opportunities for interpretative articulation and re-articulation of international exchanges that can engender, enhance, and reaffirm the reputational profile of participating actors (Cho and Kavalski 2015; Fierke and Antonio-Alfonso 2018). The inference here is that international agency emerges in a community not in a vacuum. Owing to the dynamic nature of such interactions, what passes for world order is not only constantly changing, but also demands ongoing commitment to participating in and maintaining relations (Acharya 2007; Kavalski 2017b; Ling 2015). Thus, to the extent that the " $16+1$ " has been able to frame a new regional reality in the eastern part of the European continent - and the various summits, committee meetings, and statements by representatives of CEE countries and China seem to confirm this - it is worthwhile interrogating the rationale for their involvement and continued participation (Benabdallah 2019; Kavalski 2007c; Pan and Kavalski 2018). The following section analyses the strategic narratives of the CEE countries. 


\section{WHY ARE CEE COUNTRIES PARTICIPATING IN THE BRI?}

Both for China and the CEE countries, the " $16+1$ " reveals an intriguing intersection of the discursive memory of the past with the context of the present and the anticipated tasks of the future (Kavalski 2007a). Instrumentally-speaking, it seems quite obvious what China's interests in the CEE region might be. On the one hand, CEE lies at the entry point of both the maritime Road and the economic Belt from Asia to Europe. Especially, since China Ocean Shipping Company (COSCO) acquired a majority share in the port of Piraeus, the CEE countries became of crucial significance to the success of the BRI initiative (Heath and Gray 2018; Kavalski 2015c). On the other hand, being either EU members and or at various stages of the EU-accession, allows China a soft entry point into the European market as well ability to advance its production capacity cooperation. For instance, the Chinese Premier Li Kequiang has indicated that after becoming a global leader in high speed rail, China needs to become a global leader in nuclear energy production and all the CEE countries have knowhow and capacities that can assist China in this project. At the same time, China is looking to increase and harmonize its cooperation with the EU through developing closer relations with the CEE members and prospective members of the union. In particular, China has strived to position the " $16+1$ " as a mechanism assisting the EU-accession of the Western Balkan countries. For instance, at the 2016 Summit in Riga (Latvia), China committed financial support to the so-called "Juncker Plan" (a comprehensive investment plan for the EU) through the BRI's Silk Road Fund. Last, but not least, the " $16+1$ " mechanism allows China trade and economic diversification from its "traditional" relations with so-called developing / third world countries (Walton and Kavalski 2017).

For the CEE countries, the instrumental incentive is also easily discernible (Heath and Gray 2018; Kavalski 2019). Since the bulk of them are already EU members they have witnessed decreasing levels of EU structural and cohesion funds. They have therefore been looking for diversification of their trade and economic relations. In this respect, the CEE countries are part of a global trend, where countries around the world are seeking to benefit from the bonanza promised by China's huge reserves and growing markets. This trend has intensified particularly since the 2008 global financial crisis, which saw decreasing levels of funding from traditional donors and investors. Yet, while such economics factors are quite obvious in the strategic rationale of CEE countries to participate in the BRI, it is insufficient for the explanation of their ongoing commitment to participate in an ever-more institutionalized arrangement such as the "16+1" (Fierke and Antonio-Alfonso 2018; Kavalski 2018b). In this respect, the study contends that while economic factors are not insignificant, for most CEE countries the BRI offers novel platform for the (re)articulation of 
domestic identity politics. Majority of these identity games relate to distinct contextualization of the international identities of CEE states in the geopolitics of current European affairs. The following analysis uncovers four distinct identity narratives that can be deciphered from the official statements of the governments of CEE states participating in the " $16+1$ ".

\section{We are Europeans}

Few would blame the international media for overlooking to report the Ukrainian Silk Road International Forum held in Kiev on the 8th November 2016. Yet, as commentators were struggling to come to terms with the shocking results from the presidential elections in the USA, the Kiev Forum seemed to presage a similarly momentous realignment in European affairs. Coming in the wake of the 5th Meeting of the Heads of Government of Central and East European Countries and China (better known as the " $16+1$ ") held in Riga (Latvia) on the 5th November 2016, the Ukrainian Silk Road Forum aimed to send a strong signal to Beijing that Ukraine is eager to be included in the " $16+1$ " mechanism. In this respect, Ukraine offers a good instance of the flaws in the economic argument that seeks to explain interest in the BRI as a rationally motivated by the attempt to secure much-needed economic investments. Ukraine is already part of the BRI connectivity project and recipient of Chinese investments. Instead, OBOR and in particular Ukraine's aspiration to be included in the " $16+1$ " mechanism confirm Kiev's underlying foreign policy rationale since the dissolution of the Soviet Union - namely, that it "belongs to Europe" rather than a geopolitical reconfiguratio $\mathrm{n}$ of the "post-Soviet space" pivoted on Russia (Heath and Gray 2018; Kavalski 2002). What is different this time is that Ukraine's "European" credentials appear to be associated with a project promoted by Beijing rather than Brussels.

In this respect, for some CEE countries OBOR offers an opportunity to enact their Europeanness - in fact, their EUropeanness (i.e., either that they are worthy of EU membership or that they are model EU countries). What is particularly interesting about this strategic discourse is that such Europeanness is always articulated in the context of a perceived or actual Russian threat. In other words, the Europeanness of CEE states emerges in contrast to its absence in Russia. Latvia is a good case in point here where it has been positioning itself as a lead country in an Adriatic-Baltic-Black Seas "intermarium" infrastructure project within the BRI (Kavalski 2014). Intermarium is an interwar idea for the establishment of CEE confederation from the Baltics to the Black Sea that would protect the region from either German or Russian domination. In its current iteration, the intermarium idea is framed as providing a "European" bulwark against Russia's growing assertiveness and perceived panache for meddling in the 
internal affairs of CEE states. While Poland and the Baltic States (Latvia, Lithuania, and Estonia) pursued the intermarium initiative under the aegis of the EU through the establishment in 2008 of the Baltic to Black Sea Alliance in Riga (Latvia), it seems that the BRI has provided a new medium for the articulation of that idea and has allowed its expansion to include the Adriatic littoral CEE states. In this setting, the BRI offers a novel opportunity for articulating anti-Russian sentiments (which might resonate with quite a few of the other post-Soviet BRI partners) in the context of asserting the liberal political and economic values of CEE countries (Katrandzhiev 2018; Kavalski 2015b).

\section{We are independent (of the EU) Europeans}

At the same time - and perhaps paradoxically - OBOR has provided opportunity to assert the independence of CEE states from the alleged "dictatorship" of the EU. Such non-EU Europeanness appears associated with disregard for liberal democracy and attempts to affiliate closer with Russia. The Czech Republic, Poland, and Hungary are the most conspicuous instance of such shift in the normative compass of CEE states. In this respect, Beijing (and by extension the BRI project) is seen as a partner to Russia that provides alternative model for economic and political development. In the words of the Hungarian PM Viktor Orbán, "we [the Hungarian government] are doing our best to find ways of parting with Western European dogmas, making ourselves independent from them and organizing our political community in a way that can make us competitive in this great world-race." Likewise, the Czech President Miloś Zeman proclaimed during the 2016 visit of Xi Jinping to the country - the first ever by a Chinese head of state - that the Czech Republic is "once again and independent country" and no longer "submissive to the pressure from the US and from the EU" (Kavalski 2016b; Ling 2019).

The association between China and the pro-Russian sentiments of some CEE countries makes the BRI a particularly productive vehicle for channelling their aspirations for foreign policy independence. And by foreign policy independence, most of these CEE countries understand independence from the Brussels-based institutions - both the EU and NATO (Heath and Gray 2018; Kavalski 2013b). Yet, it is not merely the Euro-Atlantic institutions that are the issue for these CEE countries, but the very idea and practices of liberal democracy that underpin them. Hence, the " $16+1$ " mechanism provides these CEE countries with an alternative normative framework for the legitimation of their governance model. For instance, the Hungarian PM Viktor Orbán (2016) was speaking for many of his counterparts when at the closing of the " $16+1$ " summit in Riga he declared that while Brussels "is struggling with the problem of economic stagnation, isolating ourselves from the world would be the worst 
response. We believe that we must open up and clearly it is beneficial for us to open up to China" (Horesh and Kavalski 2014; Katrandzhiev 2018). The implication is that China is an ideational alternative to the EU-focused foreign policy imagination of the CEE states.

\section{We are distinct East Europeans}

The BRI initiative has also been used for the internal differentiation between the CEE countries. The intention has been to demonstrate that some of the CEE countries are more valuable (that is, more deserving) of Chinese investment than the other. Again, this is not a new phenomenon and such differentiation emerged in the context of the EU-accession process during the 1990s. All the post-communist countries were competing for poll position in the race for membership. As a result, all of them were spinning strategic yarns about who is the "more European" of them all. Thus, in the internal hierarchy of CEE, Slovenia and the Visegrad countries of Poland, Hungary, the Czech Republic, and Slovakia held the top place for the most European from the former Soviet Bloc countries, followed by the Baltic states. In third place were the Southeast European states of Bulgaria and Romania (Katrandzhiev 2018; Kavalski 2008). The bottom rung was reserved for the countries of the Western Balkans - the former Yugoslav states and Albania. This hierarchy seemed confirmed by the EU accession process, which was staged following this differentiation. As a result, while the countries from the first three groups are already full EU members, from the fourth group, only Croatia has been able to join the Brussels-based club (Kavalski 2006a).

The advent of the BRI has yet again rekindled intra-CEE rivalry about how is "the most deserving" CEE state. In particular, the Visegrad grouping which to all intents and purposes went defunct after the 2004 EU enlargement round - has been revived so that it can secure more Chinese investments for the four CEE states (Benabdallah 2019; Fierke and Antonio-Alfonso 2018; Kavalski 2012a). Also, just like with the case of EU accession, when the Visegrad label provided merely instrumental framework for cooperation between Poland, Hungary, the Czech Republic and Slovakia, while each of them actively pursued bilateral relations with Brussels, it appears similar utilitarianism drives the donning of the Visegrad identity in the context of the "16+1" (Heath and Gray 2018; Kavalski 2012b). It appears therefore that rather than cooperation, the BRI seems to have intensified competition among the CEE states, which contravenes the Silk Roads Spirit that Beijing seeks to promote. 


\section{We are who we say we are}

The BRI has also been used by the CEE states to assert their own self-identification. Macedonia is the most prominent instance of this strategic discourse (Kavalski 2016a). The country probably has the most contested international identity of all CEE states. Owing to a dispute with neighbouring Greece, ever since the dissolution of Yugoslavia in 1991, Macedonia's officially recognized name has been "FYROM" (which stands for the Former Yugoslav Republic of Macedonia). It was only in the wake of allegedly Russian-sponsored coup attempts in both Macedonia and neighbouring Montenegro that Athens and Skopje reached an agreement in late 2017 on referring to the country as the "Republic of Northern Macedonia". In the context of this protracted name dispute, it is quite interesting that the country has been participating in the "16+1" mechanism under its constitutional appellation - the "Republic of Macedonia". It was in the context of the negotiations between Greece and Macedonia over the country's name that a graffiti appeared in the downtown Exarcheia neighbourhood of Athens, calling on all sides to "stop arguing, Macedonia is Chinese anyway" (Kavalski 2018a; Vangeli 2017). Playing on the absurdity of the name dispute between Greece and Macedonia, the graffiti was also being ironic about the new economic realities in the region where key infrastructure and services were being acquired by Chinese investors regardless of the formal "national" labels associated with them.

Likewise, it is quite significant that China has supported Serbia's claim over the territory of Kosovo by refusing to include it as a participant in the " $16+1$ " mechanism. This seems to support the national self-identification of Serbia, which sees the region of Kosovo as a breakaway province (not unlike Taiwan), which is an integral to the country's statehood and subject-formation (Kavalski 2015a). This Chinese stance is in accordance with its long-standing opposition to what it calls "splittism" - the violent cessation of a territory from the rest of a country (Heath and Gray 2018; Zolkos and Kavalski 2007). In this respect, China's support for Serbia's sovereignty is not merely strategic opportunism, but also has to do with Beijing's commitment to the inviolability of national sovereignty and non-interference in the domestic affairs of states (Fierke and Antonio-Alfonso 2018; Kavalski 2005). China's insistence on sovereignty reflects a normative strategy for nurturing mutual expectations premised on respect for each other's integrity. In this sense, the BRI reflects China's understanding of what it means to be a responsible international stakeholder and how should stability be nurtured. 


\section{CONCLUSION}

This study has sought to make an original contribution to the debates surrounding the BRI project by addressing the views, the concerns and the political as well as economic considerations of CEE states. The hope is that apart from adding new perspectives to the current conversations on the BRI, it has been able to illuminate the strategic dynamics underpinning the participation of CEE countries the " $16+1$ " mechanism. The analysis provided an overview of the "16+1" mechanism in the context of the geopolitics and history of Sino-CEE relations in the context of the " $16+1$ ". The aim is to illustrate that economics are far from the only (and probably not the main) reason for their participation in the BRI project. In particular, the analysis reveals four strategic narratives deployed by the CEE states in justification of their involvement in the BRI. These are: (i) we are Europeans; (ii) we are independent Europeans; (iii) we are distinct East Europeans; (iv) we are who we say we are (Kavalski 2018d; Vangeli 2018).

While distinct, these four discourses seem to coexist in the Sino-CEE relationship and CEE governments deploy them strategically in their relations with Beijing. In this respect, the BRI appears to be an interesting interplay between continuity and change in the perception of CEE countries of China's involvement in the region. For instance, just as during the Cold War when Sino-CEE relations appear to be subject to the context of Sino-Soviet relations, Russia appears to be an important factor in the interaction between Beijing and the CEE capitals. Yet, today, it is the perceived camaraderie between Russia and China that appears to be the key inflection of this relationship. For China, however, the quagmire of CEE identity politics presages a dangerous scenario in which Beijing might find itself choosing between contending sides on whose strategic narratives it supports. Such scenario might not be in the distant future and would affect other regions through which the BRI passes. For instance, in the Middle East, China already finds itself in a position where it has to navigate carefully the contending strategic narratives of Saudi Arabia and the United Arab Emirates, on the one hand, and Qatar and Turkey, on the other.

In other words, just like other great powers before it, China finds itself confronted with an expectations-capability gap: can it match the heightened expectations from its growing economic clout with the capabilities to deliver on these expectations (Acharya 2007; Kavalski 2018c). As part of its promotion of the BRI, China insists that its investments are not instruments for political manipulation but means for economic connectivity that can contribute meaningfully to cooperation and peace. Yet, the question is how the BRI is being appropriated and contextualized by China's partners. In the case of the " $16+1$ ", it seems that the CEE countries are using the BRI to advance distinct strategic narratives about their international identities. At the same time, rather than 
increasing cooperation between China and the EU, the "16+1" appears to have contributed to the growing hostility between Beijing and Brussels. In this respect, China appears to be unwittingly and unwillingly sucked into the history and politics of intra-European identity conflicts (Fierke and Antonio-Alfonso 2018; Zolkos and Kavalski 2008). The question that still remains to be answered is how would China respond to such identity geopolitics and, in fact, would it?

\section{REFERENCES}

Acharya, Amitav. 2007. "Regional Architecture.” World Politics 59(4),629-652. Benabdallah, Lina. 2019. "Contesting the International." Third World Quarterly 40(1), 1-17

Cho, Young Chul and Kavalski, Emilian. 2015. "Governing Uncertainty." Comparative Sociology 14(3), 429-444.

Cho, Young Chul and Kavalski, Emilian. 2018a. "European Union in Central Eurasia." Asia Europe Journal 16(1), 51-63.

Cho, Young Chul and Kavalski, Emilian. 2018b. "Worlding the Study of Normative Power." Uluslararası Illişkiler 15(57), 49-65.

Cudworth, Erica, Hobden, Stephen, and Kavalski, Emilian. 2018. Posthuman Dialogues in International Relations. London: Routledge.

Emmott, Robin. 2016. EU's Statement on South China Sea Reflects Divisions. Reuters, 15 July.

Fierke, K.M and Antonio-Alfonso, Francisco. 2018. "Language, Entanglement, and the New Silk Roads." Asian Journal of Comparative Politics 3(3), 194-206.

Heath, Ryan and Gray, Andrew. 2018. Beware of Chinese Trojan Horses in the Balkans. Politico, 27 July https://www.politico.eu/article/johannes-hahnbeware-chinese-trojan-horses-in-the-balkans-eu-warns-enlargement-politi co-podcast/

Horesh, Niv and Kavalski, Emilian. 2014. Asian Thought on China's Changing International Relations. Basingstoke: Palgrave.

Katrandzhiev, Valentin. 2018. Geopolitical Implications of 16+1. Paper at the Fifth High-Level China-CEE Think Tank Symposium, 30-31 Oct. Skopje (Macedonia).

Katzenstein, Peter (2005). World of Regions. Ithaca, NY: Cornell University Press.

Kavalski, Emilian. 2002. Whose Security: Russia in Asia? Ab Imperio 3(3), 631-641.

Kavalski, Emilian (2003a). Whether a Nation and $\cdots$ Whither if One? Ab Imperio 4(1), 558-568.

Kavalski, Emilian (2003b). "The International Socialization of the Balkans." 
Review of International Affairs 2(4), 71-88.

Kavalski, Emilian. 2004. From the Crescent to the Circle of Security? Historia 7(1), 87-100.

Kavalski, Emilian. 2005. “The Balkans after Iraq “ Iraq after the Balkans: Who's next?" Perspectives on European Politics and Societies 6(1), 103-127.

Kavalski, Emilian. 2006a. "From the Western Balkans to the Greater Balkans Area." Mediterranean Quarterly 17(3), 86-100.

Kavalski, Emilian. 2006b. "We Are the Hawks of Freedom." Journal of Slavic Military Studies 19(1), 271-280.

Kavalski, Emilian. 2006c. "Divide and Reward." Journal of Political and Military Sociology 34(2), 289-299.

Kavalski, Emilian. 2007a. "The Fifth Debate and the Emergence of Complex International Relations Theory." Cambridge Review of International Affairs 20(3),435-454.

Kavalski, Emilian. 2007b. Whom to Follow? China Report 43(1),43-55.

Kavalski, Emilian. 2007c. "Do Not Play with Fire". Journal of Muslim Minority Affairs 27(1), 25-36.

Kavalski, Emilian. 2008. Extending the European Security Community. London. I.B. Tauris.

Kavalski, Emilian. 2009. China and the Global Politics of Regionalization. London: Routledge.

Kavalski, Emilian. 2010a. An Elephant in a China Shop? In M.Laruelle (ed) China and India in Central Asia. Basingstoke: Palgrave: 41-60.

Kavalski, Emilian. 2010b. The Grass was Always Greener in the Past. In I.P. Karolewski and A.M. Suszycki (eds) Multiplicity of Nationalism in Contemporary Europe. Lanham, MD: Lexington Books, 213-237

Kavalski, Emilian. 2011. "Coming to Terms with the Complexity of External Agency." Journal of Eurasian Studies 2(1), 21-29.

Kavalski, Emilian. 2012a. Central Asia and the Rise of Normative Powers. New York: Bloomsbury.

Kavalski, Emilian. 2012b. Ashgate Research Companion to Chinese Foreign Policy. Aldershot: Ashgate.

Kavalski, Emilian. 2013a. "The Struggle for Recognition of Normative Powers." Cooperation and Conflict 48(2), 247-267.

Kavalski, Emilian. 2013b. Chinese Normative Communities of Practice. In China-Africa Relations in an Era of Great Transformations. Edited by L. Xing and A.O. Farah. London: Routledge, 49-70

Kavalski, Emilian. 2014. "The Shadows of Normative Power in Asia." Pacific Focus 29(3), 303-328.

Kavalski, Emilian. 2015a. Inside/Outside and Around: Observing the Complexity of Global Life. In World Politics at the Edge of Chaos. Edited by Emilian 
Kavalski. Albany, NY: State University of New York Press, 1-23.

Kavalski, Emilian. 2015b. Encounters with World Affairs. London: Routledge.

Kavalski, Emilian (2015c). India's Bifurcated Look to 'Central Eurasia'. In The

Oxford Handbook of Indian Foreign Policy, ed. D.M. Malone, C. Raja

Mohan, S. Raghavan. Oxford: Oxford University Press, 424-436.

Kavalski, Emilian. 2016a. "Relationality and Its Chinese Characteristics." China Quarterly 226, 551-559.

Kavalski, Emilian. 2016b. "China: A Relational Normative Power." Review of Global Politics 1(3), 1-20.

Kavalski, Emilian. 2017a. "Recognizing Normative State Action in International Life." Political Studies Review, 15(2), 231-242.

Kavalski, Emilian. 2017b. "Relational Knowledge-Production in International Relations." Korean Political Science Review 51(6), 147-170.

Kavalski, Emilian. 2018a. The Guanxi of Relational International Theory. London: Routledge.

Kavalski, Emilian. 2018b. "Guanxi or What is the Chinese for Relational Theory of World Politics." International Relations of the Asia-Pacific 18(3), 268-291.

Kavalski, Emilian. 2018c. "The Guanxi of Relational International Affairs." Chinese Political Science Review 3(3), 233-51.

Kavalski, Emilian. 2018d. "Community of Values or Community of Practice?

Worlding the Study of Region-Building." East Asian Community Review $1(1 / 2), 5-17$.

Kavalski, Emilian. 2019. Chinese Concepts and Relational International Politics.

In Widening the World of International Relations. Edited by E.Eydinli and

G.Biletkin. London: Routledge, 95-111.

Ling, L.H.M. 2015. The Dao of World Politics. London: Routledge.

Ling, L.H.M. 2018. "Heart and Soul for World Politics." International Relations of the Asia-Pacific 18(3), 313-337.

Ling, L.H.M. 2019. Three-ness. Politics 39(1), 1-15.

Ling, L.H.M. and Perrigoue, Alisha. 2018. OBOR and the Silk Road Ethos. Asian Journal of Comparative Politics 3(3), 207-218.

Liu Zuokai. 2017. "China-CEEC Cooperation.” Croatian International Relations Review 23(78), 19-34.

McCullock, Matthew and Kavalski, Emilian. 2005. "Pre-Westphalian Suggestions for a Post-Westphalian World." Atlantic Journal of World Affairs 1(1), 106-127.

Neumann, Iver (1999) Uses of the Other. Manchester: Manchester University Press.

Pan, Chengxin and Kavalski, Emilian. 2018. "Theorizing China's Rise in and beyond International Relations." International Relations of the Asia-Pacific 18(3), 232-241. 
Pavlićević, Dragan. 2018. 'China Threat' and 'China Opportunity' Politics of

Dreams and Fears in China-CEE Relations. Journal of Contemporary China 27(113), 688-702.

Pavlićević, Dragan and Kratz, Agatha. 2018. Testing the China Threat Paradigm. Pacific Review 31(2), 151-168.

Pempel, T.J. (2005). Remapping Asia. Ithaca, NY. Cornell University Press.

Pepe, J.P. 2017. China's Inroads into Central, Eastern, and Southeastern Europe. Berlin FDGAP.

Poggetti, Lucrezia. 2017. One China - One Europe? The Diplomat, 9 September https://thediplomat.com/2017/09/one-china-one-europe-german-foreign-m inisters-remarks-irk-beijing/

Smith, Simon and Kavalski, Emilian. 2010. NATO's Partnership. In The New Central Asia, edited by Emilian Kavalski. Singapore: World Scientific, 29-47

South China Morning Post. 2018. China Must Tread Softly in Balkans, 22 February.

The Guardian. 2017. Greece Blocks EU's Criticism at UN. 18 June.

Van Oudenaren, John S. 2018. Why Is China Wooing Eastern and Central Europe. The National Interest, September 4.

Vangeli, Anastas. 2017. "China's Engagement with the Sixteen Countries of Central, Eastern, and Southeastern Europe." China \& World Economy 25(5), 101-124.

Vangeli, Anastas. 2018. "Global China's Symbolic Power.” Journal of Contemporary China 27(113), 674-687.

Walton, David and Emilian Kavalski. 2017. Power Transition in Asia. London: Routledge.

Xinua. 2011. Full text of Chinese Premier's speech at China-Central and Eastern European Countries Economic and Trade Forum," June 26 http://www.xinhuanet. com/english2010/china/2011-06/26/c_13950035.htm. Accessed on 1 August 2018

Zolkos, Magdalena and Kavalski, Emilian. 2007. "The Hoax of War." Journal of Contemporary European Studies 15(3), 377-393.

Zolkos, Magdalena and Kavalski, Emilian. 2008. Defunct Federalisms. London: Routledge.

Zolkos, Magdalena and Kavalski, Emilian. 2016. Recognition of Nature in International Relations. In Recognition and Global Politics. Edited by Patrick Hayden and Kate Schick. Manchester: Manchester University Press, 139-156. 